\title{
Prevalence of hepatitis $C$ virus and human immunodeficiency virus in a group of patients newly diagnosed with active tuberculosis in Porto Alegre, Southern Brazil
}

\author{
Cintia Costi ${ }^{1}$, Tarciana Grandi', Maria Laura Halon', Márcia Susana Nunes Silva², \\ Cláudia Maria Dornelles da Silva', Tatiana Schäffer Gregianini', Lia Gonçalves Possuelo4, \\ Carla Adriane Jarczewski ${ }^{5}$, Christian Niel ${ }^{6 /+}$, Maria Lucia Rosa Rossetti ${ }^{1,2}$
}

\author{
${ }^{1}$ Secretaria Estadual da Saúde do Rio Grande do Sul, Fundação Estadual de Produção e Pesquisa em Saúde, \\ Centro de Desenvolvimento Científico e Tecnológico, Porto Alegre, RS, Brasil \\ ${ }^{2}$ Universidade Luterana do Brasil, Canoas, RS, Brasil \\ ${ }^{3}$ Secretaria Estadual da Saúde do Rio Grande do Sul, Fundação Estadual de Produção e Pesquisa em Saúde, \\ Instituto de Pesquisas Biológicas, Laboratório Central do Estado, Porto Alegre, RS, Brasil \\ ${ }^{4}$ Universidade de Santa Cruz do Sul, Programa de Pós-Graduação em Promoção da Saúde, Santa Cruz do Sul, RS, Brasil \\ ${ }^{5}$ Secretaria Estadual da Saúde do Rio Grande do Sul, Hospital Sanatório Partenon, Porto Alegre, RS, Brasil \\ ${ }^{6}$ Fundação Oswaldo Cruz-Fiocruz, Instituto Oswaldo Cruz, Laboratório de Virologia Molecular, Rio de Janeiro, RJ, Brasil
}

BACKGROUND Porto Alegre is the Brazilian state capital with second highest incidence of tuberculosis (TB) and the highest proportion of people infected with human immunodeficiency virus (HIV) among patients with TB. Hepatitis C virus (HCV) infection increases the risk of anti-TB drug-induced hepatotoxicity, which may result in discontinuation of the therapy.

OBJECTIVES The aim of this study was (i) to estimate prevalence of HCV and HIV in a group of patients newly diagnosed with active TB in a public reference hospital in Porto Alegre and (ii) to compare demographic, behavioural, and clinical characteristics of patients in relation to their HCV infection status.

METHODS One hundred and thirty-eight patients with TB were tested for anti-HCV antibody, HCV RNA, and anti-HIV1/2 antibody markers. HCV RNA from real-time polymerase chain reaction (PCR)-positive samples was submitted to reverse transcription and PCR amplification. The 5' non-coding region of the HCV genome was sequenced, and genotypes of HCV isolates were determined.

FINDINGS Anti-HCV antibody, HCV RNA, and anti-HIV antibodies were detected in 27 [20\%; 95\% confidence interval (CI), 13-26\%], 17 (12\%; 95\% CI, 7-18\%), and 34 (25\%; 95\% CI, 17-32\%) patients, respectively. HCV isolates belonged to genotypes 1 $(\mathrm{n}=12)$ and $3(\mathrm{n}=4)$. Some characteristics were significantly more frequent in patients infected with HCV. Among them, nonwhite individuals, alcoholics, users of illicit drugs, imprisoned individuals, and those with history of previous TB episode were more commonly infected with HCV $(\mathrm{p}<0.05)$.

MAIN CONCLUSIONS HCV screening, including detection of anti-HCV antibody and HCV RNA, will be important to improving the management of co-infected patients, given their increased risk of developing TB treatment-related hepatotoxicity.

Key words: HCV - tuberculosis - coinfection - genotypes - HIV - Southern Brazil

Tuberculosis (TB), an infectious disease caused by Mycobacterium tuberculosis, remains a major public health problem in many countries. In Brazil, the incidence of TB was estimated at 42-46 cases per 100,000 people/year (WHO 2015a). Porto Alegre, a city located in Southern Brazil, is the state capital with the second highest $(89 / 100,000)$ TB incidence in the country (MS 2016). The ongoing HIV/AIDS pandemic is one of the greatest challenges facing TB control, because HIV-induced immunosuppression increases the risk of latent TB activa-

doi: 10.1590/0074-02760160352

Financial support: PPSUS-FAPERGS/MS/CNPq/SESRS (grant no 1257-2551/13-8).

+Corresponding author: niel@ioc.fiocruz.br

Received 3 August 2016

Accepted 15 December 2016 tion considerably (Braun et al. 1993). In Brazil, about $10 \%$ of patients with TB are coinfected with HIV. In Porto Alegre, however, that proportion reaches 25\% (MS 2016). Simultaneous administration of multiple antimicrobial agents has proved to be highly effective in treating TB. In Brazil, the anti-TB regimen is composed of rifampicin, isoniazid, and pyrazinamide (RHZ). In 2010, the Ministry of Health added ethambutol to the therapeutic guidelines. However, all anti-TB regimens are known to cause hepatotoxicity (Ramappa \& Aithal 2013).

Similar to TB, hepatitis C virus (HCV) infection is an important global health issue, with 130-150 million people infected worldwide. Approximately, $15-45 \%$ of infected persons spontaneously clear the virus within six months of infection. The remaining $55-85 \%$ of infected persons develops chronic HCV infection, which, in some cases, leads to liver cirrhosis within 20 years 
(WHO 2015b). Detection of HCV RNA in the sera of anti-HCV-positive people by reverse transcription-polymerase chain reaction (RT-PCR) allows virus carriers (HCV RNA-positive people) to be distinguished from individuals who were infected but have cleared the virus (HCV RNA-negative people). HCV shows high genetic variability, and seven main HCV genotypes (1-7) have been identified. Genotypes 1 and 3, in this order, are the most prevalent in Brazil (Campiotto et al. 2005, da Silva et al. 2007, Lampe et al. 2013).

Hepatotoxicity is a major complication of anti-TB treatment that may result in therapy discontinuation. For this reason, liver function is tested before treatment. Although HCV coinfection has been shown to increase the risk of anti-TB drug-induced hepatotoxicity (Lomtadze et al. 2013, Kim et al. 2016) and death (Bushnell et al. 2015), patients without symptoms of liver disease are not systematically tested for anti-HCV antibody and HCV RNA before beginning anti-TB therapy.

Considering that most chronic $\mathrm{HCV}$ carriers and many HIV-infected people are unaware of their condition, the aims of this study were (i) to evaluate the prevalence of anti-HCV antibody, HCV RNA, and anti-HIV markers in a group of patients newly diagnosed with active TB in a public hospital of Porto Alegre, and (ii) to compare demographic, behavioural, and clinical characteristics of the patients in relation to their $\mathrm{HCV}$ infection status.

\section{MATERIALS AND METHODS}

Samples - Plasma samples were collected in a previous study (Possuelo et al. 2008) from patients attending the outpatient section of Sanatório Partenon Hospital, a public TB reference hospital located in Porto Alegre, Rio Grande do Sul, Brazil. At the time of blood collection (August 2005-June 2007), patients provided demographic, clinical, and epidemiological data in response to a questionnaire, as well as written informed consent for use of their samples in more than one study. In 2013, the Research Ethics Committee of Fundação Estadual de Produção e Pesquisa em Saúde approved the use of these samples for the present study (registration number CAAE 13878213.0.0000.5320).

All patients were adults ( $>18$ years), newly diagnosed with active $T B$, and ready to start daily treatment with RHZ, as recommended by the Brazilian National Tuberculosis Program at the time of sample collection. Active TB was diagnosed after a complete medical evaluation that included clinical examination, chest radiograph, sputum smear microscopy, and mycobacterial culture. Out of a total of 669 patients examined, the 138 patients included in this study were those who met all three requirements: (i) individuals whose hepatitis B surface antigen (HBsAg), anti-HCV antibody, and antiHIV1/2 antibody test results were available, (ii) individuals who did not show clinical signs of liver disease, and (iii) individuals who did not show elevated levels of transaminases or bilirubin (more than twice the upper limit), as measured by standard laboratory tests.

Viral RNA extraction, reverse transcription, and cDNA amplification - All 138 plasma samples (aliquots of $150 \mu \mathrm{L}$ stored at $-70^{\circ} \mathrm{C}$ ) were submitted to RNA extraction using a Nucleospin RNA Virus kit (MachereyNagel, Düren, Germany) according to the manufacturer's instructions. After extraction, RNA was resuspended in $30 \mu \mathrm{L}$ of water, and 40 units of RNaseOUT Ribonuclease Inhibitor (Invitrogen, Carlsbad, CA) was added. RNA was stored at $-70^{\circ} \mathrm{C}$ until use.

HCV RNA $(13 \mu \mathrm{L})$ was submitted to reverse transcription, and the $3^{\prime}$-X-tail element of the viral genome was amplified by real-time PCR performed on a final volume of $30 \mu \mathrm{L}$ using a Superscript III Platinum One Step qRT-PCR Kit (Invitrogen) with previously described (Drexler et al. 2009) oligonucleotide primers XTF5 and HCMgR2 (670 nM each) and HCV-specific probe HCVMGB2 $(170 \mathrm{nM})$. RT-PCR was performed using a 7500 Real-Time PCR System (Applied Biosystems, Foster City, CA) at $50^{\circ} \mathrm{C}$ for $30 \mathrm{~min}$ and $95^{\circ} \mathrm{C}$ for $2 \mathrm{~min}$, followed by 55 cycles at $95^{\circ} \mathrm{C}$ for $20 \mathrm{~s}$ and $55^{\circ} \mathrm{C}$ for $45 \mathrm{~s}$. The limit of detection was $50 \mathrm{IU} / \mathrm{mL}$. All assays were performed in duplicate.

HCV genotyping - HCV RNAs extracted from samples that were positive by real-time PCR were amplified by conventional reverse transcription-PCR using a Superscript One-Step RT-PCR System with Platinum Taq DNA polymerase (Invitrogen). This reaction was performed with $13 \mu \mathrm{L}$ of RNA in a final volume of $50 \mu \mathrm{L}$. The oligonucleotide primers HCV1 and HCV2 used in the reaction (600 $\mathrm{nM}$ each) were described previously (Krug et al. 1996). After RT at $45^{\circ} \mathrm{C}$ for $30 \mathrm{~min}, \mathrm{PCR}$ amplification was performed with 55 cycles at $94^{\circ} \mathrm{C}$ for $30 \mathrm{~s}, 55^{\circ} \mathrm{C}$ for $30 \mathrm{~s}$, and $72^{\circ} \mathrm{C}$ for $30 \mathrm{~s}$, followed by a final elongation for $5 \mathrm{~min}$ at $72^{\circ} \mathrm{C}$.

Amplicons (260-bp fragments of the conserved 5' non-coding region of the HCV genome) were purified with a PureLink PCR Purification Kit (Life Technologies, Carlsbad, CA). Nucleotide sequencing was carried out in both directions using a BigDye Terminator v3.1 Cycle Sequencing Kit (Applied Biosystems), and sequencing reactions were performed in a 3130xl Genetic Analyzer (Applied Biosystems).

HCV genotypes were determined using the Basic Local Alignment Search Tool (BLAST) algorithm (http:// blast.ncbi.nlm.nih.gov/Blast.cgi), which calculates the percent homology between a given nucleic acid query sequence and sequences of $\mathrm{HCV}$ isolates of known genotypes in the database.

Statistical analysis - Qualitative variables were compared using a $\chi^{2}$ test or Fisher's exact test as appropriate. Quantitative variables were analysed using a Student's $t$-test or Mann-Whitney $U$ test (two groups) for normally and non-normally distributed data, respectively.

All analyses were performed using SPSS version 12.0 software for Windows (SPSS Inc., Chicago, IL). All statistical tests were evaluated at a 0.05 significance level.

\section{RESULTS}

Of 138 serum samples, 27 [20\%; 95\% confidence interval (CI), 14-27\%] were anti-HCV positive. HCV RNA was detected in 14 of these samples, as well as in three of the 111 anti-HCV negative samples (Figure). Thus, a to- 


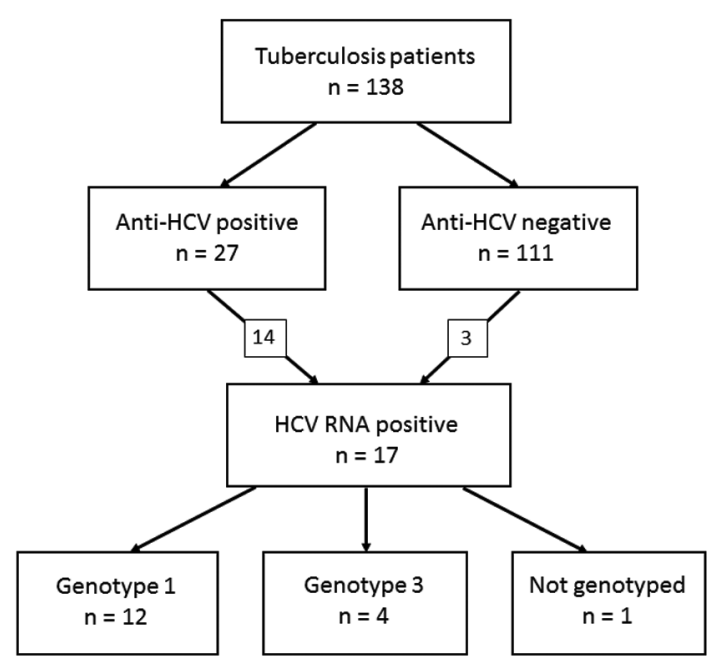

Detection of anti-hepatitis C virus (HCV) antibodies and HCV RNA in serum samples of Brazilian patients with tuberculosis and $\mathrm{HCV}$ genotypes.

tal of $17(12 \%, 95 \%$ CI, 8-19\%) patients were HCV RNA positive. HCV genotypes of 16/17 (94\%) RNA samples were determined. Twelve belonged to genotype 1 , and four belonged to genotype 3. In addition, 34/138 (25\%) patients were tested positive for anti-HIV.

Table shows the demographic, behavioural, and clinical characteristics of the patients with TB under study. Patients were 18-75 years old (mean $\pm \mathrm{SD}, 38.0 \pm 12.9$ years). Two-thirds $(67 \%$; 95\% CI, 59-75\%) were males, $57 \%$ (95\% CI, 49-65\%) were whites, and 25\% (95\% CI, $18-32 \%)$ were coinfected with HIV. In a comparison of patients positive for anti-HCV antibodies and/or HCV RNA ( $\mathrm{n}=30)$ and anti-HCV antibody- and HCV RNAnegative subjects $(\mathrm{n}=108)$, a significantly higher proportion $(60 \%$ vs. $38 \%)$ of non-white people was observed in the first group. Illicit drug use, alcohol abuse, history of incarceration, current pulmonary $\mathrm{TB}$, and a previous TB episode were characteristics that were significantly more frequent in $\mathrm{HCV}$-positive patients than in those that were HCV negative. Furthermore, the proportion of HIV-infected patients was two-fold higher among HCV-positive patients (40\%; 95\% CI, 25-58\%) than among HCV-negative patients (20\%; 95\% CI, 14-29\%) $(\mathrm{p}<0.05)$. As expected, mean alanine aminotransferase (ALT) and aspartate aminotransferase (AST) levels were only slightly higher in the HCV-positive patients (Table), because patients with evidence of chronic liver disease were excluded from the study.

\section{DISCUSSION}

An anti-HCV prevalence of 1.1-1.6\% has been estimated in the urban Brazilian population (Pereira et al. 2013). In 2010, Porto Alegre reported the second highest hepatitis $C$ rate (40.4 cases/100,000 inhabitants) among the Brazilian state capitals (MS 2012). Anti-HCV prevalence rates are generally higher among patients with TB than in the general population. In this study, 27/138
(20\%) adult patients newly diagnosed with TB tested anti-HCV positive. This proportion was comparable to rates (12-22\%) previously reported in Argentina (Pando et al. 2008) and Georgia (Richards et al. 2006, Lomtadze et al. 2013) and significantly higher than that (7\%) reported in Taiwan (Wang et al. 2011).

Most studies on TB-HCV coinfection have used anti$\mathrm{HCV}$ antibody as the sole marker of infection, without testing for HCV RNA. However, testing for both markers, as in this study, is more appropriate, because the anti-HCV positive/HCV RNA-negative pattern is common, due to high (15-45\%) rates of spontaneous HCV clearance (WHO 2015b). This pattern is expected to increase in the near future because of the advent of new HCV therapies that completely eliminate the virus (Pawlotsky 2014). Although less common, anti-HCV-negative/HCV RNA positive results can be observed either in very recent infections (immunological window period) or with immunodeficiency. For example, in this study, one of the three anti-HCV negative/ HCV RNA-positive patients was infected with HIV. When anti-HCV antibodies are not detectable, the use of molecular techniques to recognise HCV RNA are required (Kamili et al. 2012, Firdaus et al. 2015).

The regimen currently used to treat patients with $\mathrm{TB}$ has hepatotoxic effects, which can be compounded with $\mathrm{HCV}$ coinfection. Because most chronic HCV carriers and many HIV-infected people are unaware of their condition, the aims of this study were (i) to evaluate the prevalences of HCV and HIV infection in a group of patients newly diagnosed with active TB in a public reference hospital in Porto Alegre, Brazil, and (ii) to compare demographic, behavioural, and clinical characteristics of patients in relation to the HCV status. The present study differed from a previous one performed in the same hospital a few years earlier (Nader et al. 2010). In this study, we tested for viral RNA, which allowed us to distinguish 'true' HCV carriers from people who had been infected but cleared the virus. HCV RNA was thus detected in 14 of 27 anti-HCV positive patients, as well as in three of 111 anti-HCV-negative ones. The proportion of patients with TB that were HCV carriers $(17 / 138,12 \%)$ was about eight times higher than that observed in the urban Brazilian population, despite the fact that patients with elevated serum transaminase levels were excluded from this study. Such high rates of HCV may be clinically significant, considering that the incidence of abnormal liver function tests (and even mortality) with anti-TB treatment is higher in HCV-infected individuals than in the non-infected (Nader et al. 2010, Lomtadze et al. 2013, Mo et al. 2014).

HCV coinfection was associated with skin colour, illicit drug use, alcohol abuse, history of incarceration, previous TB, and anti-HIV1/2 positivity (Table). Some of these associations, such as the use of illicit drugs (Sirinak et al. 2008), history of incarceration (Richards et al. 2006), and HIV infection (Reis et al. 2011), have been observed previously in Asia and the Americas.

In Buenos Aires, Argentina, anti-HCV and anti-HIV prevalences of $12 \%$ and $17 \%$, respectively, were determined in a group of 205 patients with TB (Pando et al. 2008). In another study from Central Brazil, the corresponding pro- 
TABLE

Demographic, behavioural, and clinical characteristics of patients with tuberculosis and a comparison of characteristics between patients positive for hepatitis $\mathrm{C}$ virus (HCV) by one infection marker or negative by both

\begin{tabular}{|c|c|c|c|c|}
\hline \multirow[b]{2}{*}{ Feature } & \multirow[b]{2}{*}{ Total $(n=138)$} & \multicolumn{3}{|c|}{ HCV infection markers (anti-HCV and HCV RNA) } \\
\hline & & At least one $(n=30)$ & Both negative $(\mathrm{n}=108)$ & $\mathrm{p}$ value \\
\hline \multicolumn{5}{|l|}{ Demographic data } \\
\hline Age, $\mathrm{M} \pm \mathrm{SD}$ (years) & $38.0 \pm 12.9$ & $41.1 \pm 10.1$ & $37.2 \pm 13.5$ & NS \\
\hline Sex (male) & $93(67 \%)$ & $24(80 \%)$ & $69(64 \%)$ & NS \\
\hline \multicolumn{5}{|l|}{ Skin colour } \\
\hline White & $79(57 \%)$ & $12(40 \%)$ & $67(62 \%)$ & $<0.05$ \\
\hline Non white & $59(43 \%)$ & $18(60 \%)$ & $41(38 \%)$ & \\
\hline \multicolumn{5}{|l|}{ Behaviour } \\
\hline Cohabiting with partner & $74(54 \%)$ & $18(64 \%)$ & $55(51 \%)$ & NS \\
\hline Illicit drug use & $29(21 \%)$ & $12(40 \%)$ & $17(16 \%)$ & $<0.05$ \\
\hline Alcohol abuse & $18(13 \%)$ & $11(37 \%)$ & $7(7 \%)$ & $<0.001$ \\
\hline Tobacco use & $64(47 \%)$ & $18(56 \%)$ & $46(43 \%)$ & NS \\
\hline History of incarceration & $10(7 \%)$ & $5(17 \%)$ & $5(5 \%)$ & $<0.05$ \\
\hline \multicolumn{5}{|l|}{ Tuberculosis } \\
\hline Pulmonary tuberculosis & $117(85 \%)$ & $30(100 \%)$ & $87(81 \%)$ & $<0.05$ \\
\hline Extrapulmonary tuberculosis & $21(15 \%)$ & $0(0 \%)$ & $21(20 \%)$ & \\
\hline History of previous tuberculosis & $26(19 \%)$ & $10(33 \%)$ & $16(15 \%)$ & $<0.05$ \\
\hline \multicolumn{5}{|l|}{ Laboratory data } \\
\hline Anti-HIV1/2 positive & $34(25 \%)$ & $12(40 \%)$ & $22(20 \%)$ & $<0.05$ \\
\hline HBsAg positive & $1(1 \%)$ & $1(4 \%)$ & $0(0 \%)$ & NS \\
\hline $\mathrm{ALT}, \mathrm{M} \pm \mathrm{SD}(\mathrm{IU} / \mathrm{L})$ & $28.7 \pm 18.9$ & $30.7 \pm 19.1$ & $28.1 \pm 18.9$ & NS \\
\hline $\mathrm{AST}, \mathrm{M} \pm \mathrm{SD}(\mathrm{IU} / \mathrm{L})$ & $28.6 \pm 18.2$ & $35.0 \pm 20.4$ & $26.8 \pm 17.2$ & $<0.05$ \\
\hline Total bilirubin, $\mathrm{M} \pm \mathrm{SD}(\mathrm{mg} / \mathrm{dL})$ & $0.43 \pm 0.33$ & $0.50 \pm 0.54$ & $0.42 \pm 0.24$ & NS \\
\hline
\end{tabular}

NS: not significant.

portions were $7.5 \%$ and $28 \%$, respectively (Reis et al. 2011). Although the proportion of anti-HIV-positive patients $(25 \%)$ was similar to that in the studies cited above, the rate of anti-HCV-positive individuals (20\%) was higher in this study. This may be explained by regional variations in $\mathrm{HCV}$ prevalence. Indeed, as previously mentioned, Porto Alegre presents one of the highest rates of hepatitis $\mathrm{C}$ among the Brazilian state capitals (MS 2012).

The prevalence of HIV infection was twice as high in $\mathrm{TB} / \mathrm{HCV}$-coinfected patients $(40 \%)$ as in patients infected with TB only (20\%) (Table). This result was in agreement with those of recent studies performed in Brazil (Reis et al. 2011) and China (Mo et al. 2014). In Thailand, a study revealed a very high (31\%) anti-HCV prevalence among HIV/TB-coinfected patients (Sirinak et al. 2008). In all cases, high rates of $\mathrm{TB}, \mathrm{HCV}$, and HIV coinfection are likely a result of the high proportion ( $21 \%$ in this study) of injecting drug users in the populations under study (Friedland 2010).

According to the World Health Organization (WHO 2016), in 2014, at least one-third of people living with HIV worldwide were infected with TB bacteria. At the same time, the number of cases of hepatitis $\mathrm{C}$ infection and related diseases increased over the last two decades (Lozano et al. 2012). However, the effect of chronic hep- atitis $\mathrm{C}$ on patients with TB or coinfected with TB and HIV has not been evaluated well. HCV infection is not a contraindication for anti-TB treatment, which is administered as a standard regimen. However, the monitoring schedule may change, since such patients may require closer laboratory monitoring than those who are uninfected. HCV screening, including anti-HCV antibody and HCV RNA detection, will be important to improving the management of coinfected patients, given their increased risk of developing hepatotoxicity as a consequence of anti-TB treatment. We therefore suggest routine HCV screening, as commonly performed for HIV, in places with known high HCV prevalences.

The fact that all of the patients in this study were from the same hospital was a limitation of the study. However, the sample was representative of the larger population because the hospital is a reference centre for TB and drug-resistant TB cases, and it is located in a region that serves a population of 180,000 , with pockets poverty and indigence among them. Another limitation is the small number of patients included in the study. Despite these limitations, data presented here can contribute to addressing the TB-HCV coinfection problem in Brazil and may help public health authorities to make decisions related to screening of patients and selection of treatment protocols. 


\section{ACKNOWLEDGEMENTS}

To the staff of the outpatient department in the Sanatorio Partenon Hospital, for their assistance. We thank Drs Gisela Unis and Elis Regina Dalla Costa, for their helpful comments on the manuscript, and Drs Sidia Maria Callegari Jacques and Rúbia Marília de Medeiros, for their help with the statistical analysis.

\section{AUTHORS' CONTRIBUTION}

CC and MLRR - Conceived and designed the experiments; LGP and CAJ - collected the samples and obtained clinical data from the patients; CC, TG, MLH and TSG - performed the experiments; CC, CMDS and MSNS - analysed the data; CC, MSNS and MLRR - contributed reagents/materials/analysis tools; $\mathrm{CC}$ and $\mathrm{CN}$ - wrote the paper.

\section{REFERENCES}

Braun MM, Coté TR, Rabkin CS. Trends in death with tuberculosis during the AIDS era. JAMA. 1993; 269(22): 2865-8.

Bushnell G, Stennis NL, Drobnik AM, Proops DC, Ahuja SD, Bornschlegel K, et al. Characteristics and TB treatment outcomes in TB patients with viral hepatitis, New York City, 2000-2010. Epidemiol Infect. 2015; 143(9): 1972-81.

Campiotto S, Pinho JR, Carrilho FJ, da Silva LC, Souto FJ, Spinelli $\mathrm{V}$, et al. Geographic distribution of hepatitis $\mathrm{C}$ virus genotypes in Brazil. Braz J Med Biol Res. 2005; 38(1): 41-9.

da Silva CMD, Costi C, Krug LP, Ramos AB, Grandi T, Gandolfi VL, et al. High proportion of hepatitis $C$ virus genotypes 1 and 3 in a large cohort of patients from Southern Brazil. Mem Inst Oswaldo Cruz. 2007; 102(7): 867-70.

Drexler JF, Kupfer B, Petersen N, Grotto RM, Rodrigues SM, Grywna $\mathrm{K}$, et al. A novel diagnostic target in the hepatitis $\mathrm{C}$ virus genome. PLoS Med. 2009; 6(2): e31.

Firdaus R, Saha K, Biswas A, Sadhukhan PC. Current molecular methods for the detection of hepatitis $\mathrm{C}$ virus in high risk group population: A systematic Review. World J Virol. 2015; 4(1): 25-32.

Friedland G. Infectious disease comorbidities adversely affecting substance users with HIV: hepatitis C and tuberculosis. J Acquir Immune Defic Syndr. 2010; 55(Suppl. 1): S37-42.

Kamili S, Drobeniuc J, Araujo AC, Hayden TM. Laboratory diagnostics for hepatitis C virus infection. Clin Infect Dis. 2012; 55(Suppl. 1): S43-8.

Kim WS, Lee SS, Lee CM, Kim HJ, Ha CY, Kim HJ, et al. Hepatitis C and not hepatitis B virus is a risk factor for anti-tuberculosis drug induced liver injury. BMC Infect Dis. 2016; 16: 50.

Krug LP, Lunge VR, Ikuta N, Fonseca AS, Cheinquer H, Ozaki LS, et al. Hepatitis C virus genotypes in Southern Brazil. Braz J Med Biol Res. 1996; 29(12): 1629-32.

Lampe E, Lewis-Ximenez L, Espírito-Santo MP, Delvaux NM, Pereira SA, Peres-da-Silva A, et al. Genetic diversity of HCV in Brazil. Antivir Ther. 2013; 18(3 Pt B): 435-44.

Lomtadze N, Kupreishvili L, Salakaia A, Vashakidze S, Sharvadze L, Kempker RR, et al. Hepatitis C virus co-infection increases the risk of anti-tuberculosis drug-induced hepatotoxicity among patients with pulmonary tuberculosis. PLoS ONE. 2013; 8(12): e83892.
Lozano R, Naghavi M, Foreman K, Lim S, Shibuya K, Aboyans V, et al. Global and regional mortality from 235 causes of death for 20 age groups in 1990 and 2010: a systematic analysis for the Global Burden of Disease Study 2010. Lancet. 2012; 380(9859): 2095-128.

Mo P, Zhu Q, Teter C, Yang R, Deng L, Yan Y, et al. Prevalence, druginduced hepatotoxicity, and mortality among patients multiinfected with HIV, tuberculosis, and hepatitis virus. Int J Infect Dis. 2014; 28: 95-100.

MS - Ministério da Saúde. Hepatites Virais. Boletim Epidemiológico. Ano III. N ${ }^{\circ}$ 1. Brasília; 2012. Available from: http://www.aids. gov.br/sites/default/files/anexos/publicacao/2012/51820/boletim _ epidemiol_gico_hepatites_virais_2012_ve_12026.pdf.

MS - Ministério da Saúde. Perspectivas brasileiras para o fim da tuberculose como problema de saúde pública. Boletim Epidemiológico. 2016; 47: 1-8.

Nader LA, de Mattos AA, Picon PD, Bassanesi SL, de Mattos AZ, Rodriguez MP. Hepatotoxicity due to rifampicin, isoniazid and pyrazinamide in patients with tuberculosis: is anti-HCV a risk factor? Ann Hepatol. 2010; 9(1): 70-4.

Pando MA, de Salvo C, Bautista CT, Eyzaguirre L, Carrion G, Feola $\mathrm{M}$, et al. Human immunodeficiency virus and tuberculosis in Argentina: prevalence, genotypes and risk factors. J Med Microbiol. 2008; 57(Pt 2): 190-7.

Pawlotsky JM. New hepatitis C therapies: the toolbox, strategies, and challenges. Gastroenterology. 2014; 146(5): 1176-92.

Pereira LM, Martelli CM, Moreira RC, Merchan-Hamman E, Stein AT, Cardoso MR, et al. Prevalence and risk factors of hepatitis $\mathrm{C}$ virus infection in Brazil, 2005 through 2009: a cross-sectional study. BMC Infect Dis. 2013; 13: 60.

Possuelo LG, Castelan JA, de Brito TC, Ribeiro AW, Cafrune PI, Picon PD, et al. Association of slow N-acetyltransferase 2 profile and anti-TB drug-induced hepatotoxicity in patients from Southern Brazil. Eur J Clin Pharmacol. 2008; 64(7): 673-81.

Ramappa V, Aithal GP. Hepatotoxicity related to anti-tuberculosis drugs: mechanisms and management. J Clin Exp Hepatol. 2013; 3(1): 37-49.

Reis NR, Lopes CL, Teles SA, Matos MA, Carneiro MA, Marinho TA, et al. Hepatitis $\mathrm{C}$ virus infection in patients with tuberculosis in Central Brazil. Int J Tuberc Lung Dis. 2011; 15(10): 1397-1402.

Richards DC, Mikiashvili T, Parris JJ, Kourbatova EV, Wilson JC, Shubladze N, et al. High prevalence of hepatitis $C$ virus but not HIV co-infection among patients with tuberculosis in Georgia. Int J Tuberc Lung Dis. 2006; 10(4): 396-401.

Sirinak C, Kittikraisak W, Pinjeesekikul D, Charusuntonsri P, Luanloed P, Srisuwanvilai LO, et al. Viral hepatitis and HIV-associated tuberculosis: risk factors and $\mathrm{TB}$ treatment outcomes in Thailand. BMC Public Health. 2008; 8: 245.

Wang JY, Liu CH, Hu FC, Chang HC, Liu JL, Chen JM, et al. Risk factors of hepatitis during anti-tuberculous treatment and implications of hepatitis virus load. J Infect. 2011; 62(6): 448-55.

WHO - World Health Organization. Global tuberculosis report. 2015a. Available from: http://www.who.int/tb/publications/global_report/en/.

WHO - World Health Organization. Hepatitis C. 2015b. Fact sheet $N^{o}$ 164. Available from: http://www.who.int/mediacentre/factsheets/ fs $164 / \mathrm{en} /$.

WHO - World Health Organization. Tuberculosis. 2016. Fact sheet $N^{o}$ 104. Available from: http://www.who.int/mediacentre/factsheets/ fs104/en/. 